\title{
Lateral Percolation and Its Effect on Shale Gas Accumulation on the Basis of Complex Tectonic Background
}

\author{
Kun Zhang, ${ }^{1,2,3,4}$ Zhenxue Jiang $\mathbb{D}^{1,2}$ Xuelian Xie, ${ }^{1,2}$ Zhiye Gao $\mathbb{D}^{1,2}$ \\ Tianlin Liu, ${ }^{1,2}$ Lishi Yin, ${ }^{1,2}$ Chengzao Jia, ${ }^{4}$ Yan Song, ${ }^{1,2,4}$ Chang'an Shan, \\ Yinghui $W u,{ }^{6}$ and Pengfei Wang ${ }^{7}$ \\ ${ }^{1}$ State Key Laboratory of Petroleum Resources and Prospecting, China University of Petroleum, Beijing 102249, China \\ ${ }^{2}$ Unconventional Natural Gas Research Institute, China University of Petroleum, Beijing 102249, China \\ ${ }^{3}$ Unconventional Petroleum Collaborative Innovation Center, China University of Petroleum, Beijing 102249, China \\ ${ }^{4}$ Research Institute of Petroleum Exploration and Development, Beijing 100083, China \\ ${ }^{5}$ School of Earth Sciences and Engineering, Xian Shiyou University, Xi'an 710065, China \\ ${ }^{6}$ School of Earth Sciences and Resources, China University of Geosciences, Beijing 100083, China \\ ${ }^{7}$ Geoscience Documentation Center (CGS), Beijing 100083, China
}

Correspondence should be addressed to Zhenxue Jiang; jzxuecup@163.com and Zhiye Gao; gaozhiye@163.com

Received 18 September 2017; Accepted 13 November 2017; Published 11 January 2018

Academic Editor: Zhongwei Chen

Copyright (C) 2018 Kun Zhang et al. This is an open access article distributed under the Creative Commons Attribution License, which permits unrestricted use, distribution, and reproduction in any medium, provided the original work is properly cited.

\begin{abstract}
As a result of complex tectonic background, shale gas in China exhibits differential enrichment. Choosing a favorable exploration target accurately is a crucial problem to be solved. In this study, the tests show that there is a superior transportation pathway within shale layer. Gas in the shale layer percolates much more in the direction parallel to the plane. Therefore, the accumulation pattern of shale gas indicates a complex tectonic background. Gas in the lower part of the structure diffuses and percolates in the vertical direction into the surrounding rock. Most gas percolates towards the high part of the structure in the direction parallel to the plane. When the shale was exposed, gas percolated along the parallel direction into the air. In the case of fracture development, if there is a reverse fault, gas would be enriched in the footwall. However, if there is an unsealed fault, it would become a pathway for gas migration. The above accumulation pattern was proved in several Areas. Also, this research presented a basis of evaluation units division. According to the buried depth, fractures, and structural position, Xiuwu Basin was divided into five evaluation units and Unit A3 is the most favorable exploration target.
\end{abstract}

\section{Introduction}

Unconventional oil and gas exploration, represented by the exploration of shale oil and gas, has been a great success in North America recently because of the change in exploration concepts and the development of hydraulic fracturing technology. Similarly, China also has huge unconventional oil and gas resources, especially shale gas [1, 2]. In 2010, Well Wei 201 drilled in the Weiyuan structure achieved an industrial breakthrough of shale gas in China. In 2016, a series of progressions in shale gas commercialization was made in Changning, Zhaotong, Jiaoshiba, and Anchang. The projected shale gas production in 2020 was supposed to be $30 \times 10^{9} \mathrm{~m}^{3}$ [3]
While the shale gas exploration of China has made progression, the gas content of the different blocks varied greatly. This indicates the need for further study by petroleum geologists of the shale gas accumulation mechanism. China and North America have different geological backgrounds. America was formed by a single plate, with a large area and high rigidity. The basins did not arise through multistage tectonic movements after the deposition of shale; shale gas accumulated continuously over a large area [4-6]. In contrast, China was formed by the union of multiple plates, such as the North China Plate, Yangtze Plate, and Cathaysia Plate. The Paleozoic marine shale of South China has experienced complex multiperiod tectonic and thermal evolution, and 
the structural styles are variable which has resulted in the differential enrichment and accumulation of shale gas $[7,8]$. When the total organic carbon (TOC) content, mineral composition, and structural evolution of similar circumstances differ, the shale gas content of adjacent blocks (or different evaluation units of the same blocks) varies greatly, due to the structural position, distance from faults, and other factors.

Yang et al. (2013) summarized two shale gas accumulation patterns: the Antrim shale gas accumulation pattern in the Michigan Basin (A-pattern) and the Barnett shale gas accumulation pattern in the Delaware Basin (B-pattern). The main feature of the A-pattern is that, from the shallow periphery to the deep Basin, biogenic gas, mixed gas, and thermogenic gas occur in sequence [9-11]. The main features of the B-pattern are that the shale gas is of thermogenic origin and is indigenously generated and accumulated. Shale gas of different genetic types occurs in areas with different thermal maturities. They suggest that the Barnett shale gas accumulation pattern (B-pattern) of the Delaware Basin is of greater significance for shale gas exploration in China. However, the Antrim shale gas accumulation pattern in the Michigan Basin (A-pattern) also cannot be ignored [6, 10].

Wang et al. [12] analyzed the conditions of shale gas accumulation and divided favorable areas using TOC content, organic-rich shale thickness, maturity, mineral composition, and depth. Guo [13] put forward a theory of two-factor enrichment of marine shale gas in South China. The development of high quality marine shale on a deep continental shelf constitutes a base of hydrocarbon generation of shale gas and excellent preservation is the key to accumulation and generation of shale gas. Wang et al. [14] put forward a theory of three-factor enrichment, whose cores include the conditions of hydrocarbon generation, reservoir conditions, and shale gas preservation conditions. Based on the exploration discoveries of shale gas and research progress in relevant geological theory, as well as "source-cap controlling hydrocarbon" theory, Nie et al. [15] analyzed the main controlling factors of shale gas enrichment in the Upper Ordovician Wufeng Formation and Lower Silurian Longmaxi Formation of Sichuan Basin and its periphery. The above theory played an important role in the evaluation of shale gas under the complex tectonic background of China. However, how to choose an evaluation unit in a potential block and how to reduce exploration risk are still important problems to be solved.

Previous studies on the reservoir characteristics and shale gas exploration potential of the Lower Cambrian used the organic-rich shale's distribution characteristics, TOC, kerogen type, organic maturity, and reservoir characteristics to analyze the conditions of shale gas accumulation and to predict a favorable target area [16]. However, because the Xiuwu Basin experienced multiple depressions and extensions that caused the formation of a lot of fractures and complicated structural styles, it is hard to point a favorable and accurate exploration target simply using an index of hydrocarbon generating material basis or reservoir capacity $[14,17,18]$. In this study, a shale gas accumulation pattern was deduced and then proved through analysis of difference between the vertical and lateral permeability of shale. After that, the evaluation units of the Xiuwu Basin were divided to indicate the next step in exploration.

\section{Geological Setting}

2.1. Tectonic and Sedimentary Characteristics. The Xiuwu Basin is located southeast of the Jianghan Basin and north of the Jiangnan Uplift (Figure 1). The shale gas block, which is a part of Xiuwu Basin and includes shale gas exploration Well JiangYe 1 and JiangYe 2, is in the west part of the XiushuiWuning syncline. In the Sinian Period, the Xiuwu Basin was a craton basin, and in the Late Sinian, marine regression happened with the formation of the Piyuancun Formation, which consists of siliceous dolomite. The Wangyinpu Formation (thickness 45-50 m, organic-rich, and black siliceous shale) was deposited in the Early Cambrian while a large regression happened. Gradually, the water became shallow [19]. The clasolite sedimentary system in the Early Cambrian developed into a carbonatite sedimentary system in the Middle-Late Cambrian. The sedimentary environment changed back to shallow marine in the Early-Middle Ordovician [20]. During the Late Ordovician-Early Silurian, due to the collision of the plate, the study area was a deep-water environment caused by the extrusion. The water became shallow again in the Middle Silurian. The land was uplifted to become ancient land in the Late Silurian [21, 22]. During the Devonian and Carboniferous, periods of uplift and precipitation (erosion) intersected incessantly and little sediment was deposited during that time. The Permian and Early-Middle Triassic were also times of major precipitation. In the Late Triassic, the Xiuwu Basin began to uplift but was impacted by the collision between the North China Plate and the South China Plate $[14,23]$. Squeezed during the Early-Middle Jurassic, the study area turned into a syncline and a large number of thrust faults developed. During the Cretaceous, the squeezing stress environment of the Xiuwu Basin transferred to the extension. The stress properties of these thrust faults turned from extrusion to extension. The stress of the study area, influenced by the intrusion of the India-Australian plate onto the Eurasian plate, was changed from extension to extrusion again in the Neogene [24].

2.2. Stratigraphic Distribution. The Xiuwu Basin appears as a syncline with strata present from old to young, of the limbs to the core $[25,26]$. From bottom-up, the Sinian, Cambrian, Ordovician, Middle and Lower Silurian, Upper Devonian, Upper Carboniferous, Middle and Upper Permian, and Lower Triassic were deposited. In the southeastern and southwestern parts of the study area, the Upper Cretaceous and Paleogene alluvial fan was overlain unconformable by the eroded strata. The Wangyinpu and Guanyintang Formations of the Lower Cambrian, Xiuwu Basin, which has high total organic carbon (TOC) content, thick organic-rich shale, high degree of thermal evolution, and type I kerogen, are the target layer of shale gas exploration [27]. The lithology of underlying strata, the Piyuancun Formation of Upper Sinian, is grey siliceous dolomite. The lithology of overlying strata, the Yangliugang Formation of Middle Cambrian, is grey 


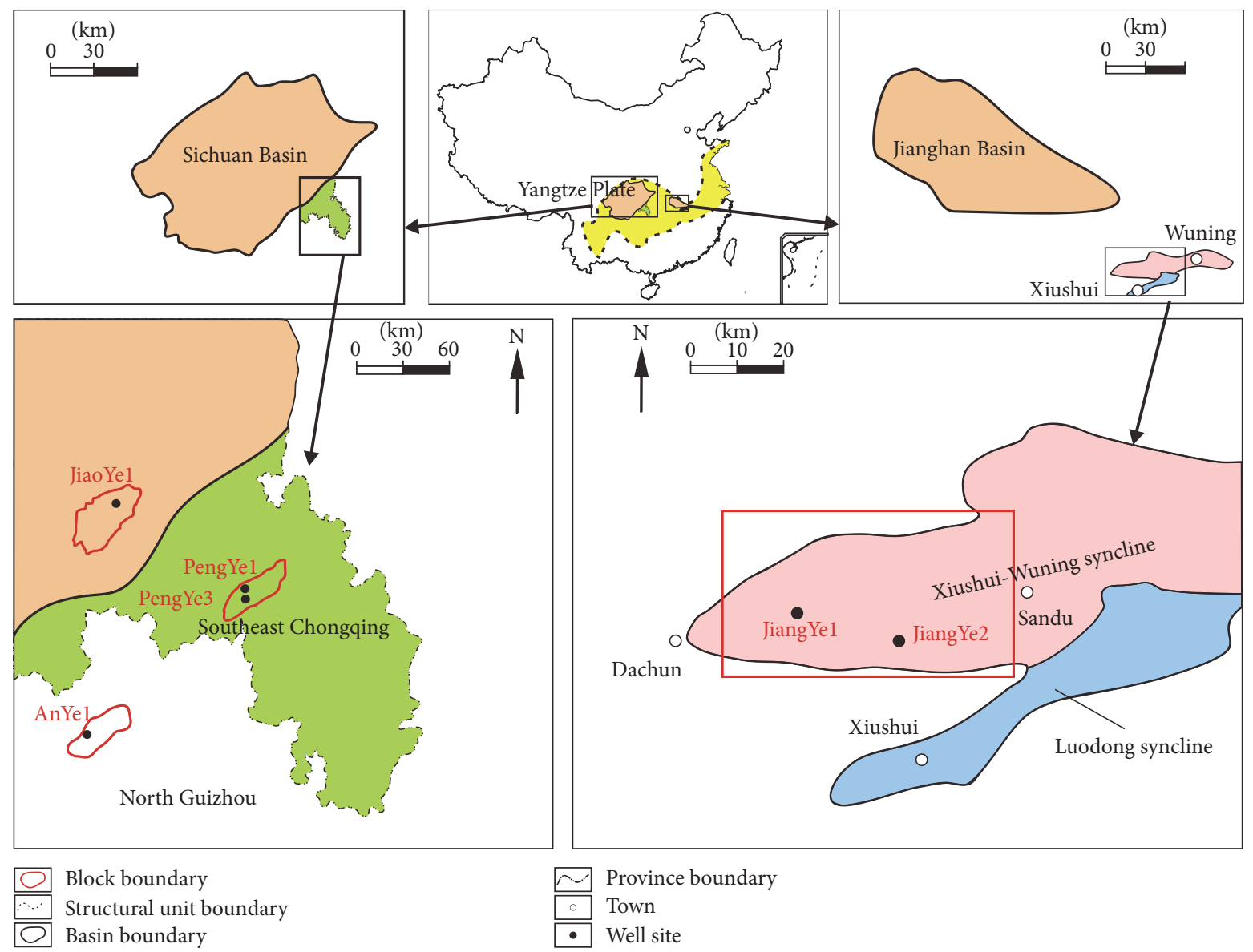

FIgURe 1: Geological map of Jiaoshiba, Anchang, Pengshui, and Xiuwu Basin with well locations.

microcrystalline limestone. Both of them are conformable contact. The stratigraphic column was shown in Figure 2.

\section{Samples and Experiments}

3.1. Permeability Test. In the Wangyinpu and Guanyintang Formations, from the bottom to the top in the Lower Cambrian of the Xiuwu Basin, 16 samples were taken from Lower Cambrian shale. 3 samples were from Well JiangYe 1 , and 13 were from Well JiangYe 2 (Table 1). TEMCO Poro PDP-200 was used to analyze the vertical and lateral pulse permeability of full diameter core samples. The permeability test pressure was $1000 \mathrm{psi}$ and the confining pressure $1500 \mathrm{psi}$. In the Longmaxi Formation, $\mathrm{He}$ et al. [28] have taken 12 samples from Lower Silurian shale of Pengshui Area, Well PengYe 1 (Table 2).

3.2. Core Immersion Test. At the drilling site of Well JiaoYe 1, Jiaoshiba Area, the core of Lower Silurian was immediately put into a sink when it was taken out of the wellhead. The size of the bubbles from the cylindrical surfaces and sections of the core, occurrence (continuous or discontinuous bubble), sound level, duration, and bubble position were all recorded.

\section{Results}

4.1. Experimental Result. The results of the permeability tests are shown in Figures 3 and 4, which illustrate that lateral permeability was 1-40 times that of the vertical permeability. This indicated the existence of a superior transportation pathway within the shale layers. The core immersion test of Lower Silurian of Well JiaoYe 1 also indicated that shale gas bubbles were mainly from a direction parallel to the plane (Figure 5). Bubbles from directions perpendicular to the plane were only a few. The results confirmed that gas in shale layers mainly percolates along the direction parallel to the plane.

4.2. Shale Gas Accumulation Pattern. For the characteristics of foliation development in shale, gas seepage has directional properties. With the compaction of shale, the sheet clay minerals tend to be parallel to the rock layer. And with the repeated superposition, plastic deformation, an excellent surface lamellation formed which made the stress in the bedding direction much weaker, and then the seepage rate increased. In the lamellation surface of organic-rich shale, the presence of microcracks increases the lateral permeability. As a result, 

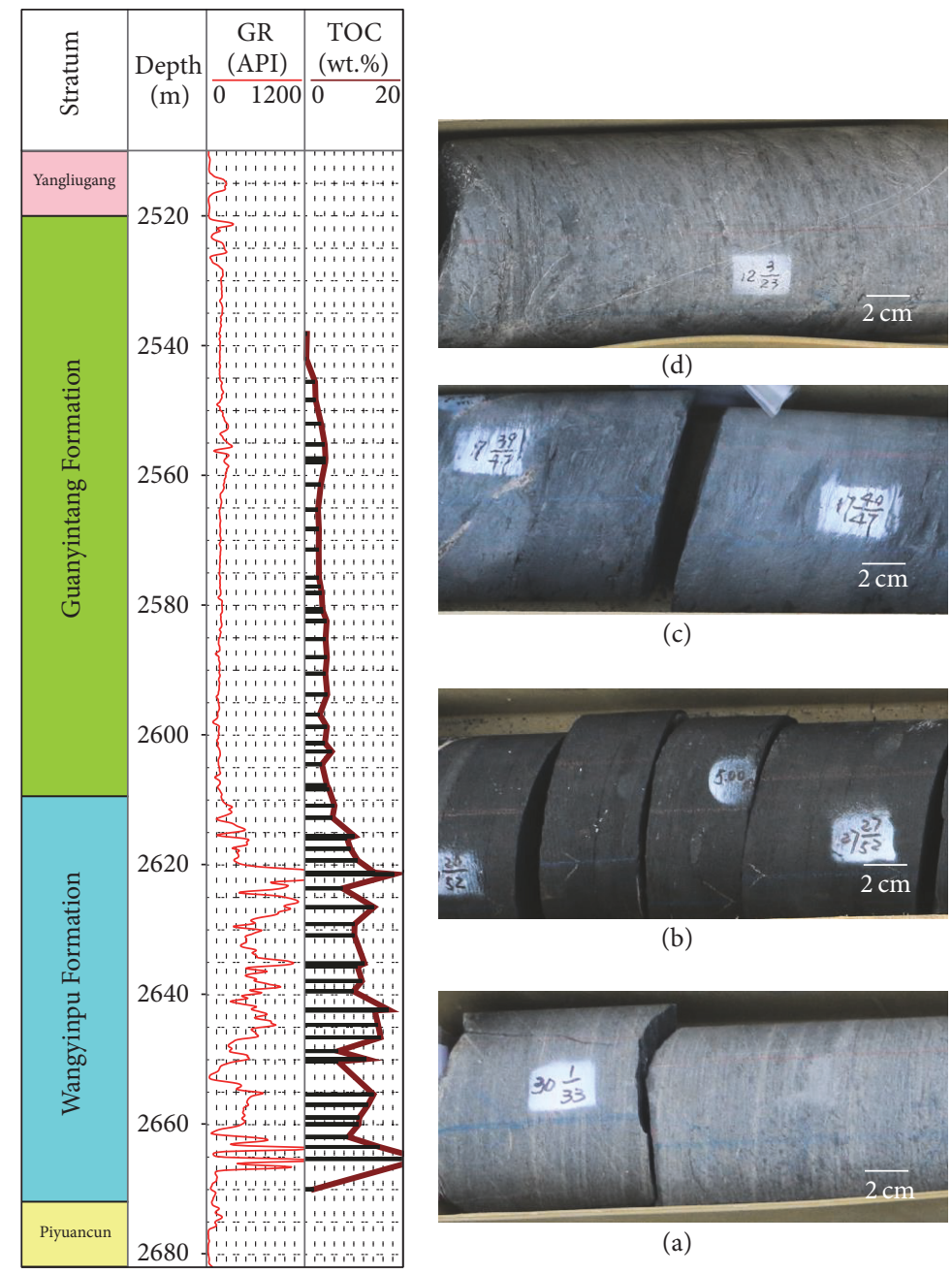

(d)

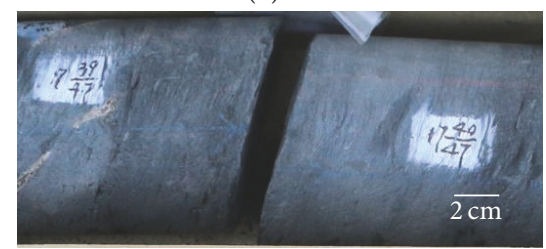

(c)

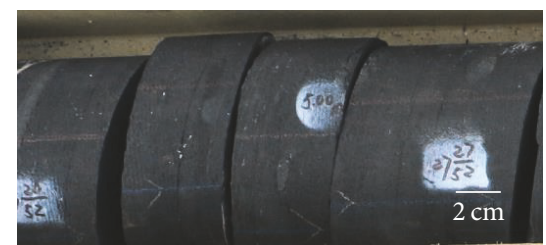

(b)

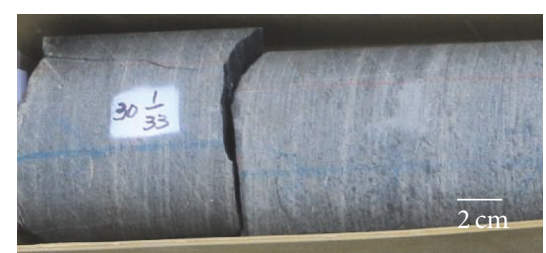

(a)

FIgure 2: A stratigraphic column and core photos of Upper Ediacaran, Lower and Middle Cambrian of Jiangye-1 well. (a) Ediacaran Piyuancun Formation 2675 m, grey siliceous dolomite. (b) Lower Cambrian Wangyinpu Formation 2638 m, dark siliceous shale. (c) Lower Cambrian Guanyintang Formation 2546 m, dark grey siliceous shale. (d) Middle Cambrian Yangliugang Formation $2511 \mathrm{~m}$, grey micrite. See Figure 1 for the location of the well site.

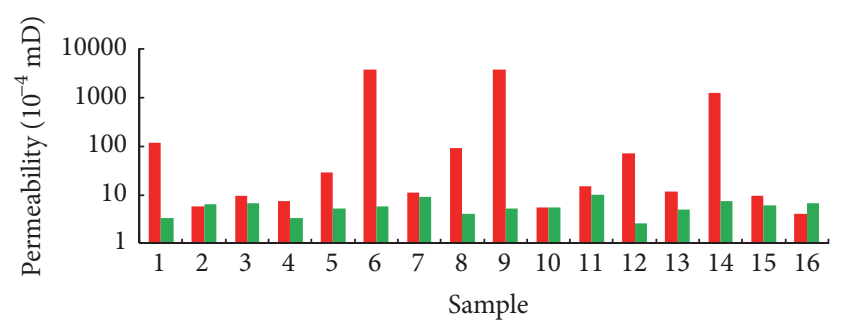

- Lateral permeability

- Vertical permeability

(a)

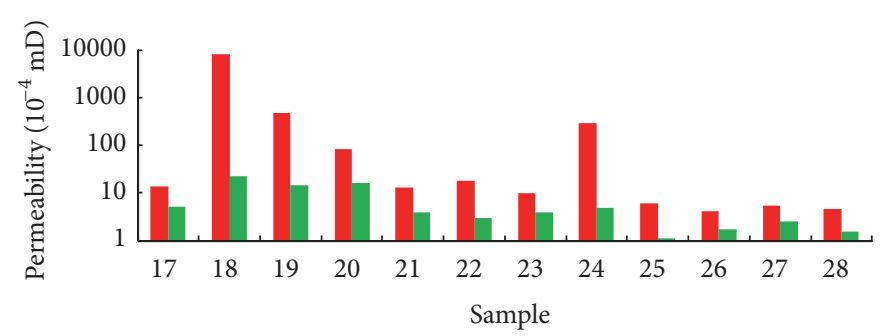

- Lateral permeability

- Vertical permeability

(b)

Figure 3: Lateral and vertical permeability histograms. (a) Samples of the Lower Cambrian shale, from Well JiangYe 1 and JiangYe 2. (b) Samples of the Lower Silurian shale, from Well PengYe 1. See Figure 1 for the well locations. 


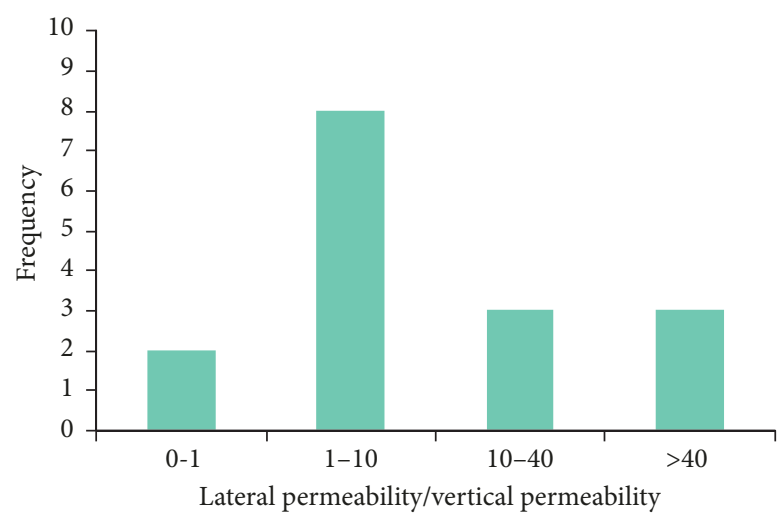

(a)

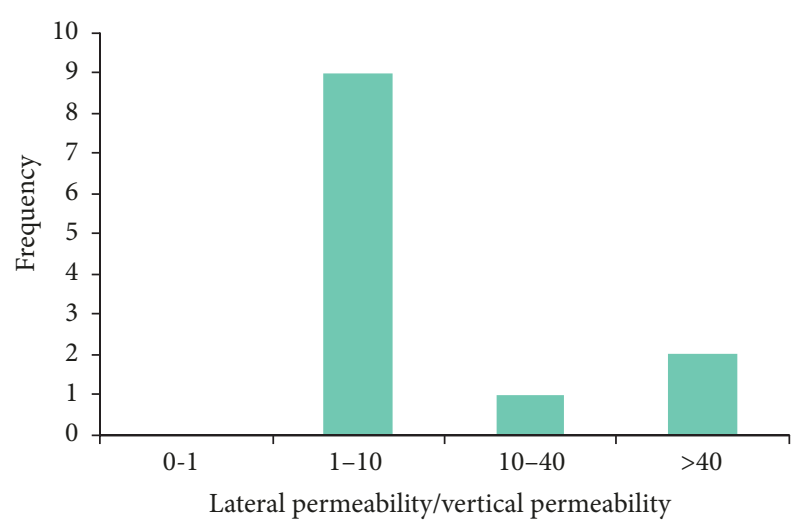

(b)

FIGURE 4: Ratio statistics between lateral and vertical permeability. (a) Samples of the Lower Cambrian shale, from Well JiangYe 1 and JiangYe 2. (b) Samples of the Lower Silurian shale, from Well PengYe 1. See Figure 1 for the well locations.

TABLE 1: Number, well, and formation of the permeability test samples.

\begin{tabular}{|c|c|c|}
\hline Number & Well & Formation \\
\hline (1) & JiangYe 1 & Guanyintang \\
\hline (2) & JiangYe 1 & Wangyinpu \\
\hline (3) & JiangYe 1 & Wangyinpu \\
\hline (4) & JiangYe 2 & Guanyintang \\
\hline (5) & JiangYe 2 & Guanyintang \\
\hline (6) & JiangYe 2 & Guanyintang \\
\hline (7) & JiangYe 2 & Guanyintang \\
\hline (8) & JiangYe 2 & Guanyintang \\
\hline (9) & JiangYe 2 & Wangyinpu \\
\hline (10) & JiangYe 2 & Wangyinpu \\
\hline (11) & JiangYe 2 & Wangyinpu \\
\hline (12) & JiangYe 2 & Wangyinpu \\
\hline (13) & JiangYe 2 & Wangyinpu \\
\hline (14) & JiangYe 2 & Wangyinpu \\
\hline (15) & JiangYe 2 & Wangyinpu \\
\hline (16) & JiangYe 2 & Wangyinpu \\
\hline (17) & PengYe 1 & Longmaxi \\
\hline (18) & PengYe 1 & Longmaxi \\
\hline (19) & PengYe 1 & Longmaxi \\
\hline (20) & PengYe 1 & Longmaxi \\
\hline (21) & PengYe 1 & Longmaxi \\
\hline (22) & PengYe 1 & Longmaxi \\
\hline (23) & PengYe 1 & Longmaxi \\
\hline (24) & PengYe 1 & Longmaxi \\
\hline (25) & PengYe 1 & Longmaxi \\
\hline$(26)$ & PengYe 1 & Longmaxi \\
\hline (27) & PengYe 1 & Longmaxi \\
\hline (28) & PengYe 1 & Longmaxi \\
\hline
\end{tabular}

the difference between vertical and lateral permeability leads to the diffusion rate of lateral much larger than that of vertical.
Curtis [9] indicated that shale gas migrates a short distance within shale layers. Researches about Jiaoshiba Areas revealed that there is no large range of migration in shale gas system. However, there must be a process of dynamic adjustment and balance in shale with high thermal maturity and complex evolution history [29-31]. When shale gas gathered in the high position, it would be lost naturally. Then, gas from the lower position would migrate a very short distance keeping the balance of accumulation and losing. Step-by-step migration of the adjacent pores has achieved the convergence of shale gas into the positive structure.

$\mathrm{Hu}$ et al. [32] used spontaneous imbibition experiments to study pore connectivity of shale. Gao and $\mathrm{Hu}$ [33] found that Barnett shale has low pore connectivity by conducting imbibition experiments. A number of previous researchers, Ji et al. [34, 35], Wang et al. [36, 37], Tang et al. [3840], and Chen et al. [41], indicated that organic matter provided most of the connected pores and that the network consisting of interconnected organic pores, microcracks, and bedding plane provided the main percolation pathway of shale gas. The accumulation pattern was deduced in the comprehensive consideration of previous studies and the experimental results, as well as related tectonism (Figure 6).

Under the action of temperature, pressure, and catalyst, the organic matter matured and started to produce gas. When the shale formation was compressed by tectonic movements, the lateral permeability would be much higher than the vertical if there was no fault and unconformity. From the low part of the structure, most of the shale gas in free-state percolated to the high part along the bedding plane, while some would diffuse and percolate to surrounding rocks. In the high part of the structure, supplementary gas from the lower part of the structure led to higher shale gas content (Figure 6(C)). If the shale formation was exposed at the surface, shale gas would percolate in the direction parallel to the plane into the air, which would lead to low gas content (Figure 6(D)). In the case of fracture development, if there were a well-sealed reverse fault, shale gas would be enriched in the footwall (Figure 6(A)). However, if there were an 
TABLE 2: Divisions of evaluation units.

\begin{tabular}{lccc}
\hline Evaluation units & Secondary evaluation units & Buried depth & Structural position \\
& A1 & $2000-3250 \mathrm{~m}$ & Slope \\
A & A2 & $2000-3250 \mathrm{~m}$ & Gentle part and near to the large south structure \\
& A3 & $3250-4000 \mathrm{~m}$ & Gentle part \\
B & A4 & $3250-4000 \mathrm{~m}$ & Slope with small fractures developed \\
C & & $<2000 \mathrm{~m}$ & Slope and near to outcrops \\
D & & $>4000 \mathrm{~m}$ & Depression part \\
E & & South side & Large fractures developed and near to outcrops \\
\hline
\end{tabular}
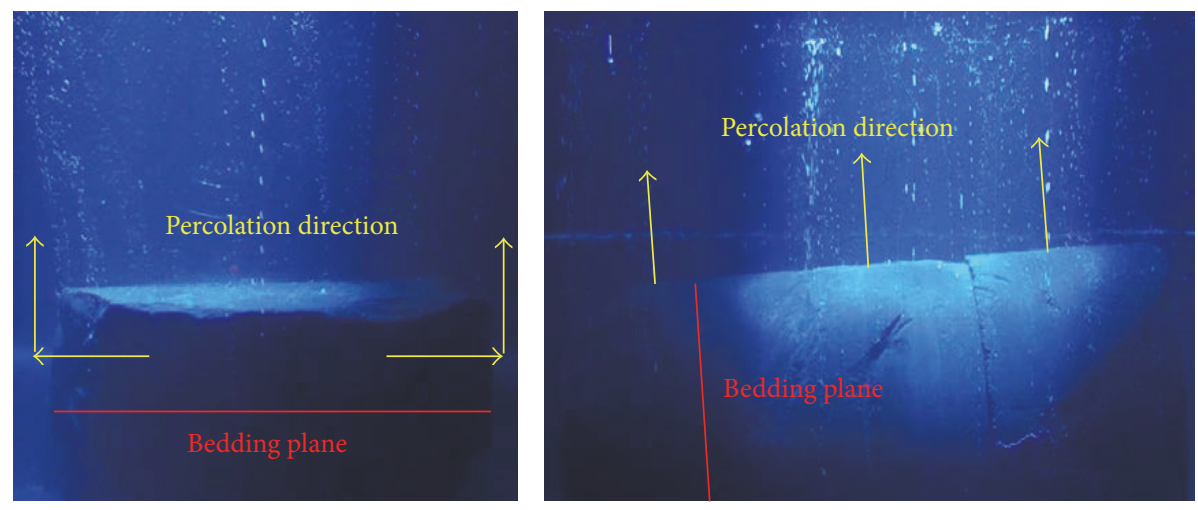

FIgURE 5: Core immersion test of Lower Silurian, from Well JiaoYel, Jiaoshiba. See Figure 1 for the location.

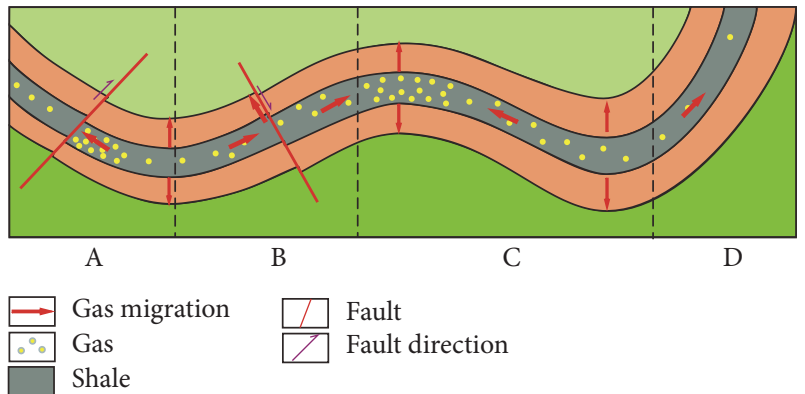

FIGURE 6: Shale gas accumulation pattern under complex tectonic background.

open fault, it would be a pathway for shale gas migration (Figure 6(B)).

\section{Discussion}

5.1. Validation of the Shale Gas Accumulation Pattern. Southeast Chongqing and North Guizhou are located in the internal-to-external transition zone of the Sichuan Basin. These areas developed anticlines, synclines, and other structural styles due to tectonic movements during the Cretaceous Period and are suitable areas to validate shale gas accumulation patterns, subjected to a complex tectonic background $[42,43]$. The following validation took place in Jiaoshiba with a typical anticline, Pengshui with an obvious syncline, and Anchang with well-sealed reverse faults.

Jiaoshiba, located on the inner side of the Sichuan Basin, is an anticline with a reverse fault on both sides. The area is well sealed because of not being subjected to tectonic extension. Thus in the direction parallel to the plane, there was little loss of shale gas (Zhou et al., 2010) [44]. According to the accumulation pattern, most of the shale gas would gather in place, except for a little diffusion and percolation into the surrounding rock. In the same time, supplementary gas rising from the lower part of the structure would increase the shale gas content (Figure 7).

Pengshui, southeast of Chongqing, located in the outside of Sichuan Basin, is a syncline as a whole with strata of both sides exposed [45-47]. According to the accumulation pattern, shale gas would migrate into the surrounding rock and then percolate to the slopes of the syncline resulting in a lower gas content than at Jiaoshiba. Although shale gas from the core would supply the limbs of the syncline, the gas would migrate through slopes because of surface exposures of the shale formation (Figure 8).

Anchang, North Guizhou, also located in the outside of the Sichuan Basin, is entirely a syncline with a reverse fault in the left limb. Analysis of the tectonic revolution showed that the well-sealed reverse faults were compressed throughout their history [46-48]. The accumulation of shale gas could be inferred on the basis of the accumulation pattern. Shale gas generated in the core would diffuse and percolate to the 


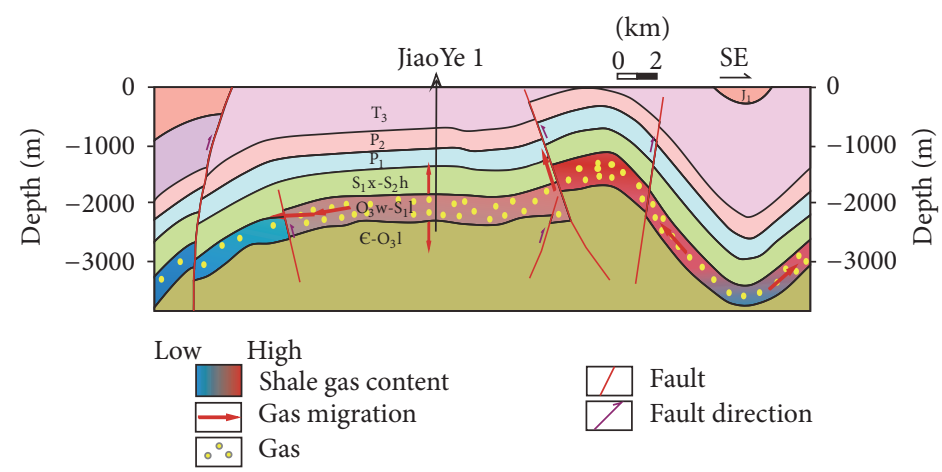

FIGURE 7: Shale gas accumulation diagram of the Jiaoshiba Area, Southeast Chongqing. See Figure 1 for the location.

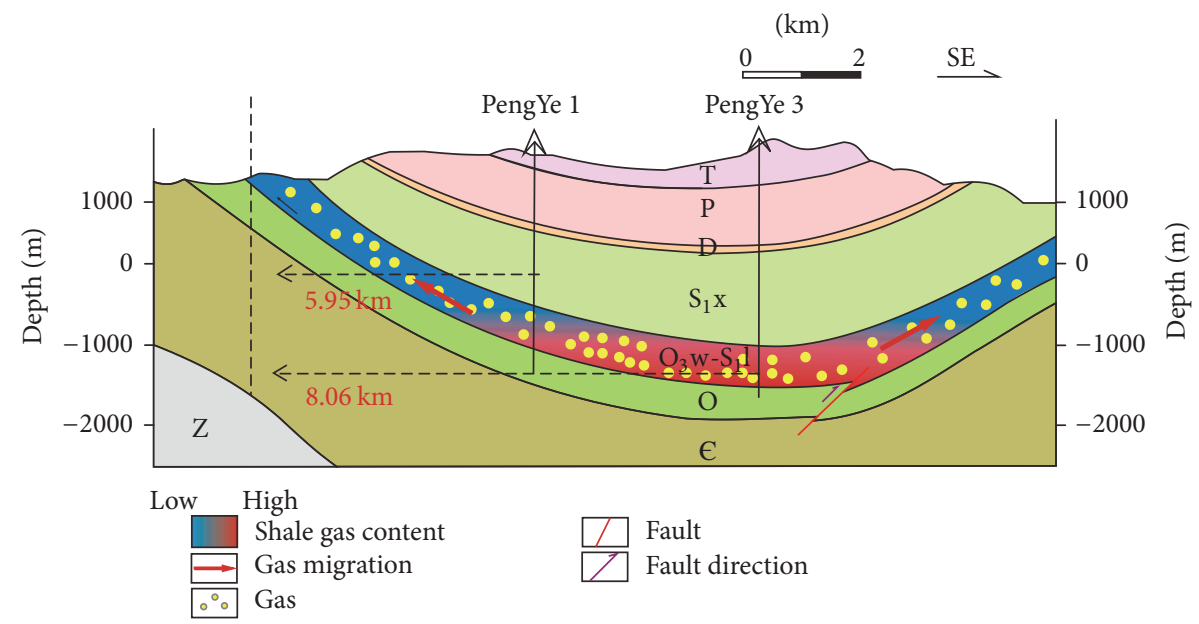

FIgURE 8: Shale gas accumulation diagram of the Pengshui Area, Southeast Chongqing. See Figure 1 for the location.

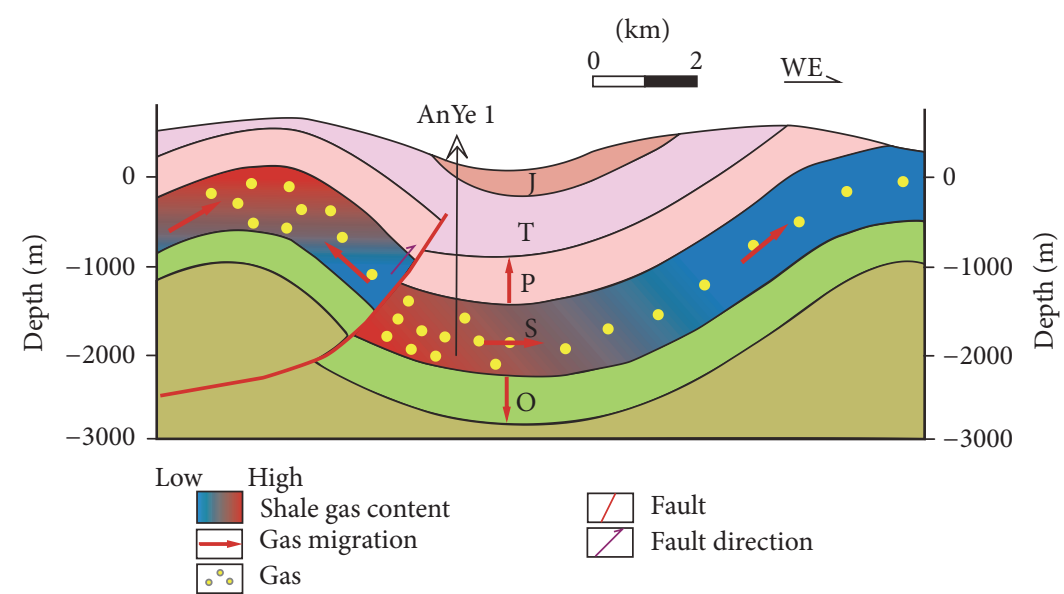

Figure 9: Shale gas accumulation diagram of Anchang Area, North Guizhou. See Figure 1 for the location.

limbs along the direction parallel to the plane, while a small part of it would diffuse vertically into the surrounding rock. Due to the good sealing property of the reverse fault in the left limb, shale gas would accumulate in the footwall of the fault. Due to exposure of the shale layer at the surface, gas of the right limb would be lost (Figure 9).
Well drilling in the Jiaoshiba, Anchang, and Pengshui Areas proved the above accumulation pattern. The gas content of Well JiaoYe 1 (Longmaxi Formation in Jiaoshiba) was $6.1 \mathrm{~m}^{3} / \mathrm{t}$, whereas the gas content of Well AnYe 1 (Longmaxi Formation) reached $6.49 \mathrm{~m}^{3} / \mathrm{t}$. However, the shale gas wells in the Pengshui Area were not in good condition. The gas 


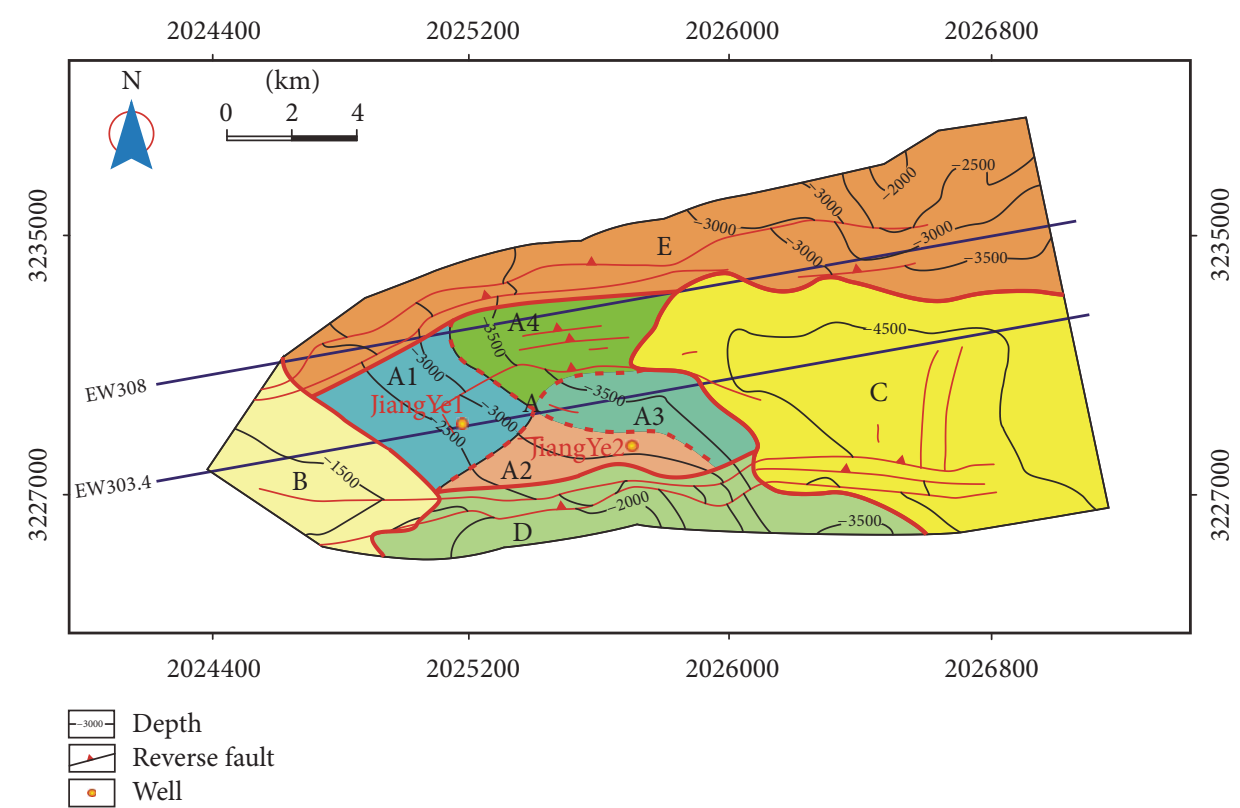

Figure 10: Division of evaluation units of the shale gas area, XiuWu Basin. See Figure 1 for the location.

content of Well PengYe 1 on the syncline slope was $1.99 \mathrm{~m}^{3} / \mathrm{t}$, and that of the Well PengYe 3 in the syncline depression was $2.79 \mathrm{~m}^{3} / \mathrm{t}$; both are less than Well JiaoYe 1 and Well AnYe 1 .

\subsection{Division of Evaluation Units in the Xiuwu Basin}

5.2.1. Basis for Division of the Evaluation Units. The exploration practices showed that shale gas reservoirs with complex tectonic backgrounds are not large areas of continuous accumulation but are composed of both rich and damaged areas. To select a favorable exploration target accurately, division of the evaluation units of the shale gas area and analysis of accumulation conditions is essential. According to the accumulation pattern, combined with the tectonic background of the Xiuwu Basin and exploration costs, in this study, buried depth, fractures, and structural styles were chosen as the basis for dividing the evaluation units.

(1) Buried Depth. The chosen study area had a buried depth between $2000-4000 \mathrm{~m}$. The reason is that the study area is a syncline with Lower Cambrian exposure in the limbs. If the buried depth was lower than $2000 \mathrm{~m}$, dips of the strata would increase rapidly, which would make diffusion of the shale gas along the bedding plane much easier. However, the vertical depth of most shale gas wells in South China is less than $4000 \mathrm{~m}$ in consideration of costs. Therefore, the buried depth of potential targets should be lower than $4000 \mathrm{~m}$.

(2) Fractures. Analysis of the tectonic evolution showed that the study area had a lot of thrust faults due to compression in Early and Middle Jurassic and was regionally stretched from Late Cretaceous to Paleogene. Although the properties of most of the thrust faults in the study area did not change, poor sealing in some faults led to the loss of shale gas along the fractures. For this reason, it was necessary to divide the evaluation units according to the scale of fault development. The north and south sides of the Xiuwu Basin developed fractures, east-west strike, and connected to the surface.

(3) Structural Position. Figure 6 shows that there is a great difference in shale gas content in different structural positions. In the slope next to the surface, the shale gas cannot become enriched because of the large migration to the outcrop. In the gentle part of the structure, supplementary gas of the lower part increased the shale gas content and the amount of lateral migration was much more, both of which facilitated the enrichment of shale gas.

5.2.2. Division Results of Evaluation Units. Figure 10 and Table 2 show the results. The study area was divided into 5 parts. The buried depth of Unit B was lower than $2000 \mathrm{~m}$ and near an outcrop that provided easy diffusion. The buried depth of Unit C was deeper than $4000 \mathrm{~m}$. Units D and E were on the south and east sides of the study area where regional fractures developed. Unit A had a moderate buried depth (2000-4000 m) and had fewer fractures that were more favorable than the other four units. In order to select the exploration target more accurately, Unit A was further divided into four secondary evaluation units.

\section{Application and Favorable Area Prediction}

Seismic line EW303.4 was deployed in the middle of the Xiuwu Basin and passed through Units A, B, C, and D. Seismic interpretation of the line and division results of the evaluation units is shown in Figure 11. The units were assessed based on the accumulation pattern of shale gas in a complex tectonic background: Unit $\mathrm{C}$ lies in the low part of the structure. On the one hand, shale gas would migrate to the surrounding rock along the direction vertical to the 


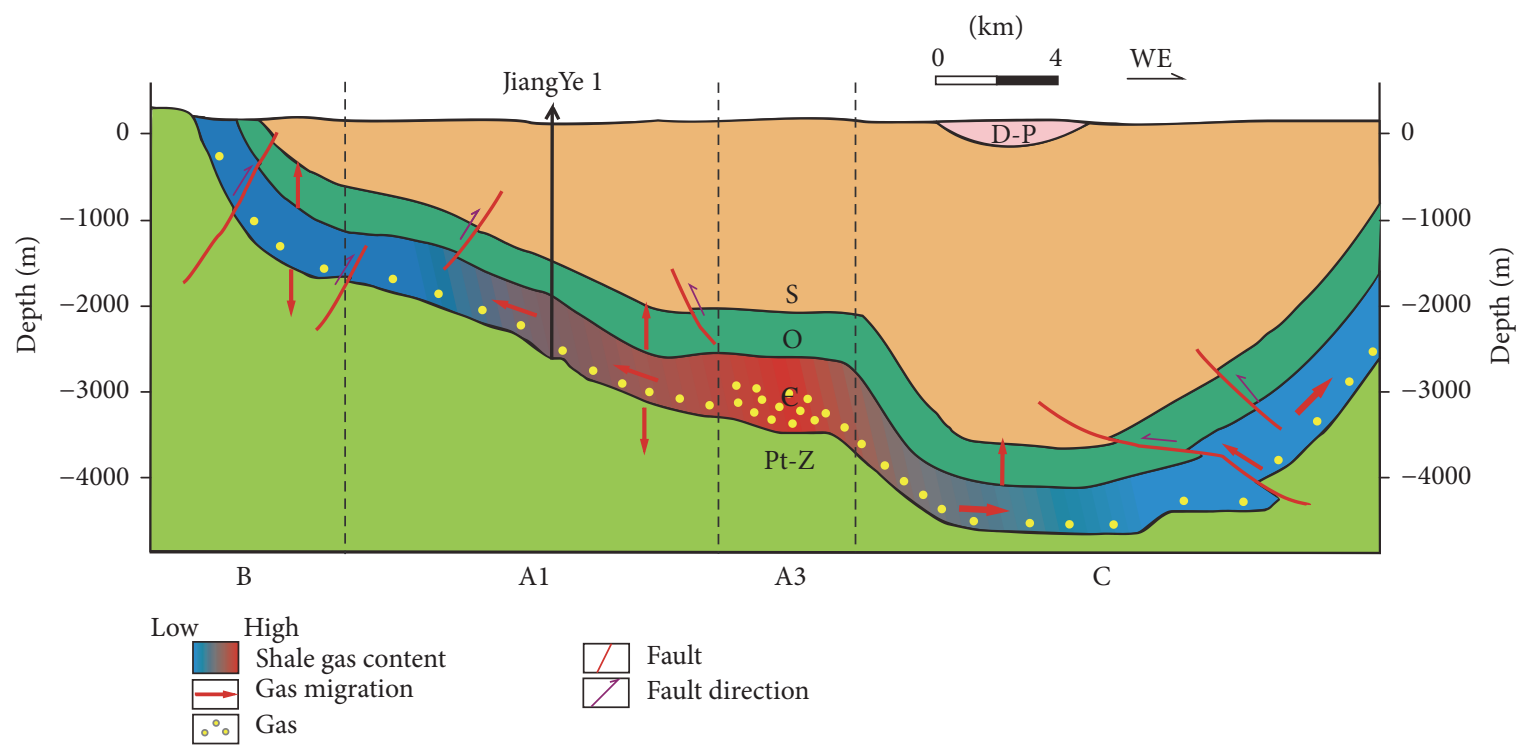

Figure 11: Evaluation units and shale gas accumulation diagram of seismic line EW303.4, Xiuwu Basin. See Figure 10 for the seismic line location.

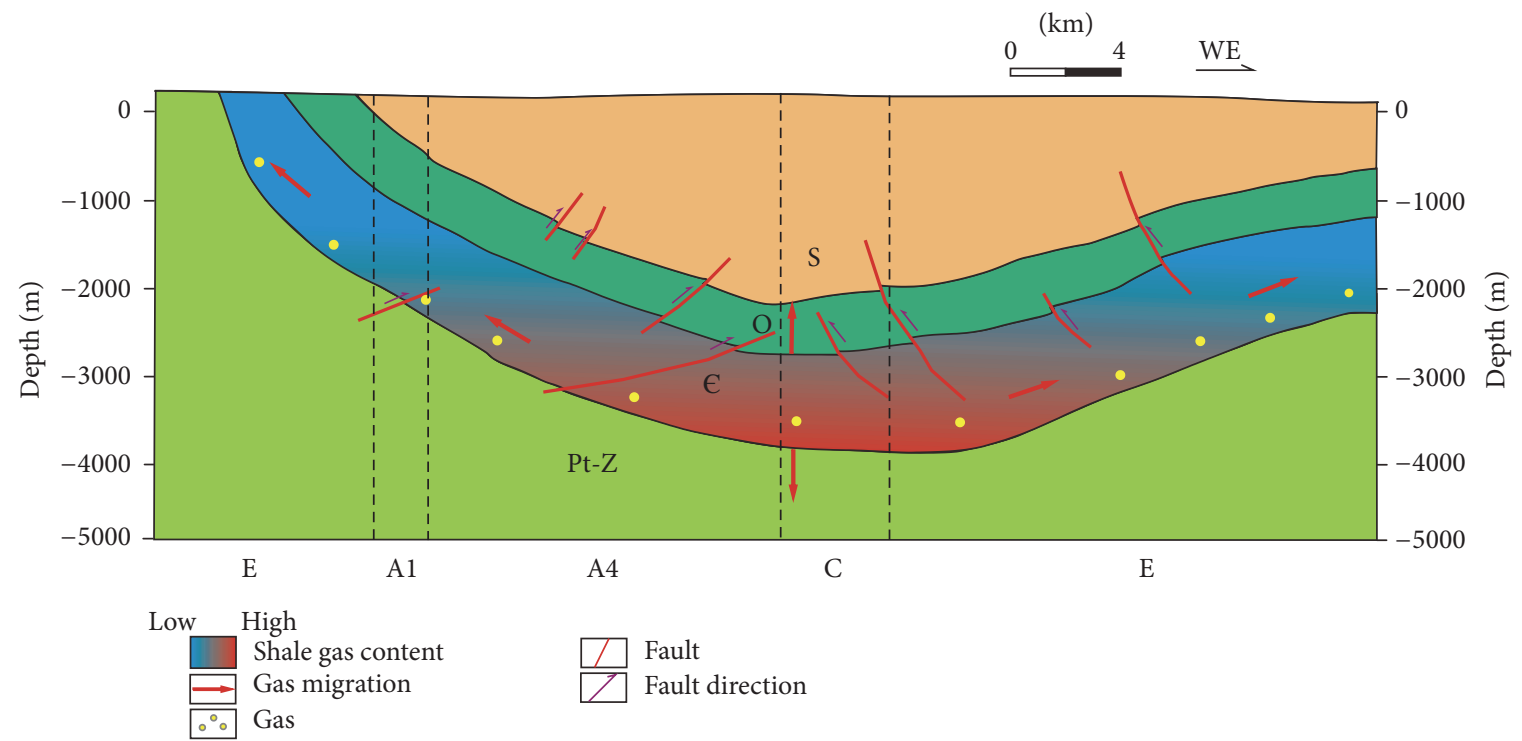

FIGURE 12: Evaluation units and shale gas accumulation diagram of seismic line EW308, Xiuwu Basin. See Figure 10 for the seismic location.

bedding plane. The opening structure would accelerate that process. On the other hand, shale gas would percolate along the bedding plane to both sides of the depression. In this process, a larger amount of shale gas would migrate to Unit A3 because of the steep slope of Unit C. Unit A3 lies in the gentle part. A small part of the shale gas would also migrate to the surrounding rock. In the direction parallel to the bedding plane, a large amount of gas would be supplied by Unit $\mathrm{C}$ and a little gas would migrate to Unit $\mathrm{Al}$ due to the steep eastern slope and to the mild western slope that has high residual shale gas content. Units A1 and B occur on the slope of the structure. Shale gas would migrate to the surrounding rock and most of it would migrate to the outcrop area since the slope is a pathway of shale gas loss. The shale gas content of Well JiangYe 1 of the Lower Cambrian in Unit Al was $0.848 \mathrm{~m}^{3} / \mathrm{t}$ on average which confirmed that a slope connected to the outcrop would not be enriched with gas.

Due to the large fracture in the south of the southern study area, most parts of the gas lost when the extension occurred from Late Cretaceous to Paleogene. The shale gas content of Well JiangYe 2 of the Lower Cambrian in Unit A2 was $1.634 \mathrm{~m}^{3} / \mathrm{t}$ on average, which is still low, although higher than JY1.

Seismic line EW308 deployed in the northern Xiuwu Basin passed through Unit A1, A4, B, and E. Figure 12 shows that Unit A1, A4, and B are slopes that have less gas. The 
extension made the fracture of Unit A4 a pathway which is a disadvantage for enrichment of the shale gas. The discussion above illustrated that Unit A3 is the most favorable area of the Xiuwu Basin.

\section{Conclusions}

Based on the difference between the vertical and lateral permeability and on the immersion test of drilling cores, it was concluded that the shale gas accumulation pattern indicated a complex tectonic background. It was proven in several areas and then applied in order to choose an exploration target of Xiuwu Basin. The conclusions are below.

(1) There is a superior transportation pathway within the shale layers. Gas percolates mainly along the direction parallel to the bedding plane and less in the direction perpendicular to the bedding plane.

(2) When the shale formation was compressed during tectonic movements and without development of faults and unconformity in the lower part of the structure, most of the shale gas percolated to the higher part along the bedding plane, while a small amount diffused and percolated to the surrounding rock. The higher part of the structure is full of shale gas because of the supplementary gas from the lower part of the structure, while a small amount of gas diffused and percolated into the surrounding rock.

(3) When the shale formation was exposed to the surface, shale gas percolated along the direction parallel to the bedding plane into the air, which resulted in low gas content. In the case of fracture development, if there was a reverse fault with good sealing, shale gas would be enriched in the footwall. However, if there was a tensioned normal fault with poor sealing, the fault would be a pathway for shale gas migration.

(4) According to buried depth, fractures, and structural position, the Xiuwu Basin was divided into 5 evaluation units; then Unit A was further divided into four secondary evaluation units. Unit A3 lies in the slope, had fewer fractures, and was a shale gas enrichment area because of the supplementary gas from Unit $\mathrm{C}$ on the steep slope and from Unit A1 on the gentle slope. Therefore, Unit A3 was the most favorable area for exploration of Xiuwu Basin.

\section{Conflicts of Interest}

The authors declare that they have no conflicts of interest.

\section{Acknowledgments}

This research was supported by the National Science and Technology Major Project (2017ZX05035-002), the Science Foundation of the Ministry of Land and Resources of China (no. 12120114046701), and the National Natural Science Foundation of China (no. 41472112).

\section{References}

[1] D. Warlick, "Gas shale and CBM development in North America," Oil \& Gas Financial Journal, vol. 3, no. 11, pp. 1-5, 2006.
[2] C. Zou, D. Dong, S. Wang et al., "Geological characteristics and resource potential of shale gas in China," Petroleum Exploration and Development, vol. 37, no. 6, pp. 641-653, 2010.

[3] W. Zhao, J. Li, T. Yang, S. Wang, and J. Huang, "Geological difference and its significance of marine shale gases in South China," Petroleum Exploration and Development, vol. 43, no. 4, Article ID 499510, pp. 499-510, 2016.

[4] D. M. Jarvie, R. J. Hill, T. E. Ruble, and R. M. Pollastro, "Unconventional shale-gas systems: the Mississippian Barnett Shale of north-central Texas as one model for thermogenic shale-gas assessment," AAPG Bulletin, vol. 91, no. 4, pp. 475-499, 2007.

[5] R. M. Pollastro, "Geologic framework of the Mississippian Barnett Shale, Barnett-Paleozoic total petroleum system, Bend arch-Fort Worth Basin, Texas," AAPG Bulletin, vol. 91, no. 4, pp. 405-436, 2007.

[6] T. J. Kinley, L. W. Cook, J. A. Breyer, D. M. Jarvie, and A. B. Busbey, "Hydrocarbon potential of the Barnett Shale (Mississippian), Delaware Basin, west Texas and southeastern New Mexico," AAPG Bulletin, vol. 92, no. 8, pp. 967-991, 2008.

[7] J. Zhang, H. Nie, B. Xu, S. Jiang, P. Zhang, and Z. Wang, "Geological condition of shale gas accumulation in Sichuan Basin," Natural Gas Industry, vol. 28, no. 2, pp. 151-156, 2008.

[8] H. Nie, S. Bao, B. Gao et al., "A study of shale gas preservation conditions for the Lower Paleozoic in Sichuan Basin and its recently, Earth Science Frontiers, vol. 19, no. 3, pp. 280-294, 2012.

[9] J. B. Curtis, "Fractured shale-gas systems," AAPG Bulletin, vol. 86, no. 11, pp. 1921-1938, 2002.

[10] R. G. Loucks and S. C. Ruppel, "Mississippian Barnett Shale: Lithofacies and depositional setting of a deep-water shale-gas succession in the Fort Worth Basin, Texas," AAPG Bulletin, vol. 91, no. 4, pp. 579-601, 2007.

[11] H. Nie and J. Zhang, "Shale gas reservoir distribution geological law, characteristics and suggestions," Journal of Central South University (Science and Technology Edition), vol. 42, no. 2, pp. $1-9,2010$.

[12] S. Wang, L. Wang, J. Huang, X. Li, and D. Li, "Accumulation conditions of shale gas reservoirs in Silurian of the upper Yangtze region," Natural Gas Industry, vol. 29, no. 5, pp. 45-50, 2009.

[13] X. Guo, "Rules of twofactor enrichment for marine shale gas in Southern China, understanding from the Longmaxi Formation shale gas in Sichuan Basin and its surrounding area," Acta Geologica Sinica, vol. 88, no. 7, pp. 1209-1218, 2014.

[14] G. Wang, Y. Ju, and K. Han, "Early Paleozoic shale properties and gas potential evaluation in Xiuwu Basin, western Lower Yangtze Platform," Journal of Natural Gas Science and Engineering, vol. 22, pp. 489-497, 2015.

[15] H. Nie, Z. Jin, R. Bian, and W. Du, "The "source-cap hydrocarbon-controlling" enrichment of shale gas in Upper Ordovician Wufeng Formation-Lower Silurian Longmaxi Formation of Sichuan Basin and its periphery," Shiyou Xuebao/Acta Petrolei Sinica, vol. 37, no. 5, pp. 557-571, 2016.

[16] W. Liu, J. Tian, X. Lin, J. Shi, C. Yang, and S. Peng, "Characteristics and significance of mineral compositions in Lower Cambrian black shale from Xiuwu Basin, Jiangxi, China," Journal of Chengdu University of Technology (Science \& Technology Edition), vol. 42, no. 1, pp. 90-97, 2015.

[17] W. Qin, Q. Han, and J. Wang, "Shale gas reservoiring condition analysis in Xiuwu Basin," Energy Research and Management, vol. 3, no. 1, pp. 46-49, 2013. 
[18] G. He, "Geological characteristics of Lower Cambrian Shale in Xiuwu Basin," in Proceedings of the Annual Meeting of Chinese Geoscience Union, Beijing, China, October 19-23, 2014.

[19] K. Xiao, H. Chen, Y. Wo, Y. Zhou, and Y. Zhang, "Impact of tectonic evolution on Paleozoic and Mesozoic petroleum systems in Jianghan plain," Oil and Gas Geology, vol. 26, no. 5, pp. 688693, 2005.

[20] F. Guo, J. Kang, J. Sun, J. Lu, and X. Wang, “Tectonic evolution and hydrocarbon accumulation model for marine strata in Jianghan Basin," Lithologic reservoirs, vol. 22, no. 1, pp. 23-29, 2010.

[21] J. Yang, F. Yi, and L. Hou, "Genesis and petrogeochemistry characteristics of Lower Cambrian black shale series in northern Guizhou," Acta Mineralologica Sinica, vol. 24, no. 3, pp. 286-291, 2004.

[22] Z. Feng, Y. Peng, Z. Jin et al., "Lithofacies paleogeography of the Cambrian in South China," Journal of Paleogeography, vol. 3, no. 1, pp. 1-14, 2001.

[23] X. Qi, Q. Hu, X. Yi, and S. Zhang, "Shale gas exploration prospect of Lower Cambrian Wangyinpu formation in Xiuwu Basin," China Mining Magazine, vol. 24, no. 10, pp. 102-107, 2015.

[24] Y. Wo, Y. Zhou, and K. Xiao, "The burial history and models for hydrocarbon generation and evolution in the marine strata in southern China," Sedimentary Geology and Tethyan Geology, vol. 27, no. 3, pp. 94-100, 2007.

[25] L. Mei, D. Deng, C. Shen, and Z. Liu, “Tectonic dynamics and marine hydrocarbon accumulation of Jiangnan-Xuefeng Uplift," Geological Science and Technology Information, vol. 31, no. 5, pp. 85-93, 2012.

[26] P. Wang, S. Li, X. Liu et al., "Yanshanian fold-thrust tectonics and dynamics in the Middle-Lower Yangtze River area, China," Acta Petrologica Sinica, vol. 28, no. 10, pp. 3418-3430, 2012.

[27] F. Pang, S. Bao, S. Ren, S. Li, C. Tong, and L. Zeng, "Shale gas accumulation conditions and favorable areas of the Lower Cambrian in Xiuwu Basin," Journal of Northeast Petroleum University, vol. 38, no. 5, pp. 23-30, 2014.

[28] X. He, Y. Gao, X. Tang, P. Zhang, and G. He, "Analysis of major factors controlling the accumulation in normal pressure shale gas in the southeast of Chongqing," Natural Gas Geoscience, vol. 28, no. 4, pp. 654-664, 2017.

[29] T. Guo, "Evaluation of highly thermally mature shale-gas reservoirs in complex structural parts of the Sichuan Basin," Journal of Earth Science, vol. 24, no. 6, pp. 863-873, 2013.

[30] T. Guo, "The Fuling Shale Gas Field-A highly productive Silurian gas shale with high thermal maturity and complex evolution history, southeastern Sichuan Basin, China," Interpretation, vol. 3, no. 2, pp. SJ25-SJ34, 2015a.

[31] T. Guo and P. Zeng, "The structural and preservation conditions for shale gas enrichment and high productivity in the WufengLongmaxi Formation, Southeastern Sichuan Basin," Energy Exploration \& Exploitation, vol. 33, no. 3, pp. 259-276, 2015b.

[32] Q. Hu, R. P. Ewing, and S. Dultz, "Low pore connectivity in natural rock," Journal of Contaminant Hydrology, vol. 133, pp. 76-83, 2012.

[33] Z. Gao and Q. Hu, "Wettability of Mississippian Barnett Shale samples at different depths: Investigations from directional spontaneous imbibition," AAPG Bulletin, vol. 100, no. 1, pp. 101114, 2016.

[34] W. Ji, Y. Song, Z. Jiang, X. Wang, Y. Bai, and J. Xing, "Geological controls and estimation algorithms of lacustrine shale gas adsorption capacity: A case study of the Triassic strata in the southeastern Ordos Basin, China," International Journal of Coal Geology, vol. 134-135, pp. 61-73, 2014.

[35] W. Ji, Y. Song, Z. Jiang et al., "Estimation of marine shale methane adsorption capacity based on experimental investigations of Lower Silurian Longmaxi formation in the Upper Yangtze Platform, south China," Marine and Petroleum Geology, vol. 68, pp. 94-106, 2015.

[36] P. Wang, Z. Jiang, L. Chen et al., "Pore structure characterization for the Longmaxi and Niutitang shales in the Upper Yangtze Platform, South China: Evidence from focused ion beamHe ion microscopy, nano-computerized tomography and gas adsorption analysis," Marine and Petroleum Geology, vol. 77, pp. 1323-1337, 2016a.

[37] P. Wang, Z. Jiang, W. Ji et al., "Heterogeneity of intergranular, intraparticle and organic pores in Longmaxi shale in Sichuan Basin, South China: Evidence from SEM digital images and fractal and multifractal geometries," Marine and Petroleum Geology, vol. 72, pp. 122-138, 2016b.

[38] X. Tang, Z. Jiang, Z. Li et al., "The effect of the variation in material composition on the heterogeneous pore structure of high-maturity shale of the Silurian Longmaxi formation in the southeastern Sichuan Basin, China," Journal of Natural Gas Science and Engineering, vol. 23, pp. 464-473, 2015.

[39] X. Tang, Z. Jiang, H. Huang et al., "Lithofacies characteristics and its effect on gas storage of the Silurian Longmaxi marine shale in the southeast Sichuan Basin, China," Journal of Natural Gas Science and Engineering, vol. 28, pp. 338-346, 2016.

[40] X. Tang, Z. Jiang, S. Jiang, L. Cheng, and Y. Zhang, "Characteristics and origin of in-situ gas desorption of the Cambrian Shuijingtuo Formation shale gas reservoir in the Sichuan Basin, China," Fuel, vol. 187, pp. 285-295, 2017.

[41] L. Chen, Z. Jiang, K. Liu et al., "Effect of lithofacies on gas storage capacity of marine and continental shales in the Sichuan Basin, China," Journal of Natural Gas Science and Engineering, vol. 36, pp. 773-785, 2016.

[42] W. Zeng, W. Ding, J. Zhang et al., "Research on the facture effectiveness of the Lower Cambrian Niutitang Shale in the sourheastern Chongqing and northern Guizhou areas," Earth Science Frontiers, vol. 23, no. 1, pp. 096-106, 2016.

[43] H. Bi, Z.-X. Jiang, P. Li et al., "Shale reservoir characteristics and its influence on gas content of Wufeng-Longmaxi Formation in the southeastern Chongqing," Natural Gas Geoscience, vol. 25, no. 8, pp. 1275-1283, 2014.

[44] J. Liu, "Application of oil-based drilling fluid in third-open section of Qinye horizontal well," Science \& Technology Information, vol. 10, no. 5, pp. 106-107, 2013.

[45] E. Xu, Z. Li, and Z. Yang, "Thermal and hydrocarbon generation history of Wufeng and Longmaxi shales in Pengshui area, eastern Sichuan Basin: a well PY1 case study," Petroleum Geology \& Experiment, vol. 37, no. 4, pp. 494-499, 2015.

[46] J. Li, B. Yu, C. Liu, and M. Sun, "Clay Minerals of Black Shale and Their Effects on Physical Properties of Shale Gas Reservoirs in the Southeast of Chongqing: A Case Study from Lujiao Outcrop Section in Pengshui, Chongqing," Geoscience, vol. 26, no. 4, pp. 732-740, 2012.

[47] J. Li, R. Xie, J. You, and L. Wang, "Reservoir forming condition and exploration prospect of shale-gas in Guizhou qianbei area," China Mining Magazine, vol. 21, no. 2, pp. 55-59, 2012.

[48] J. He, Y. Duan, X. Zhang, B. Wu, and L. Xu, "Hydrocarbon Generation Condtions of the Shale in Niutitang Formation of Lower Cambrian, Southern Chongqing and Northern Guizhou," Marine Geology Frontiers, vol. 27, no. 7, pp. 34-40, 2011. 

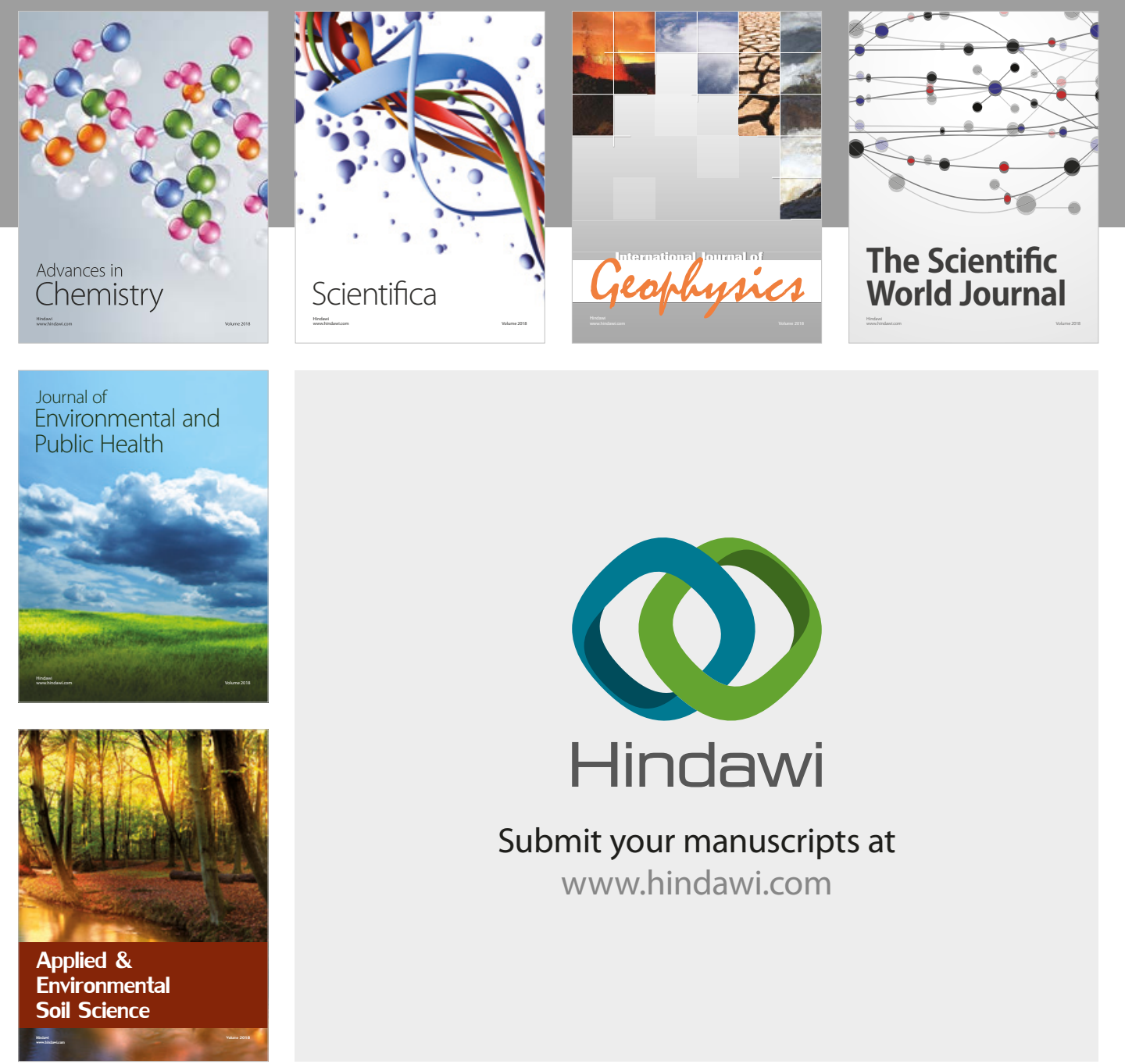

The Scientific

\section{World Journal}
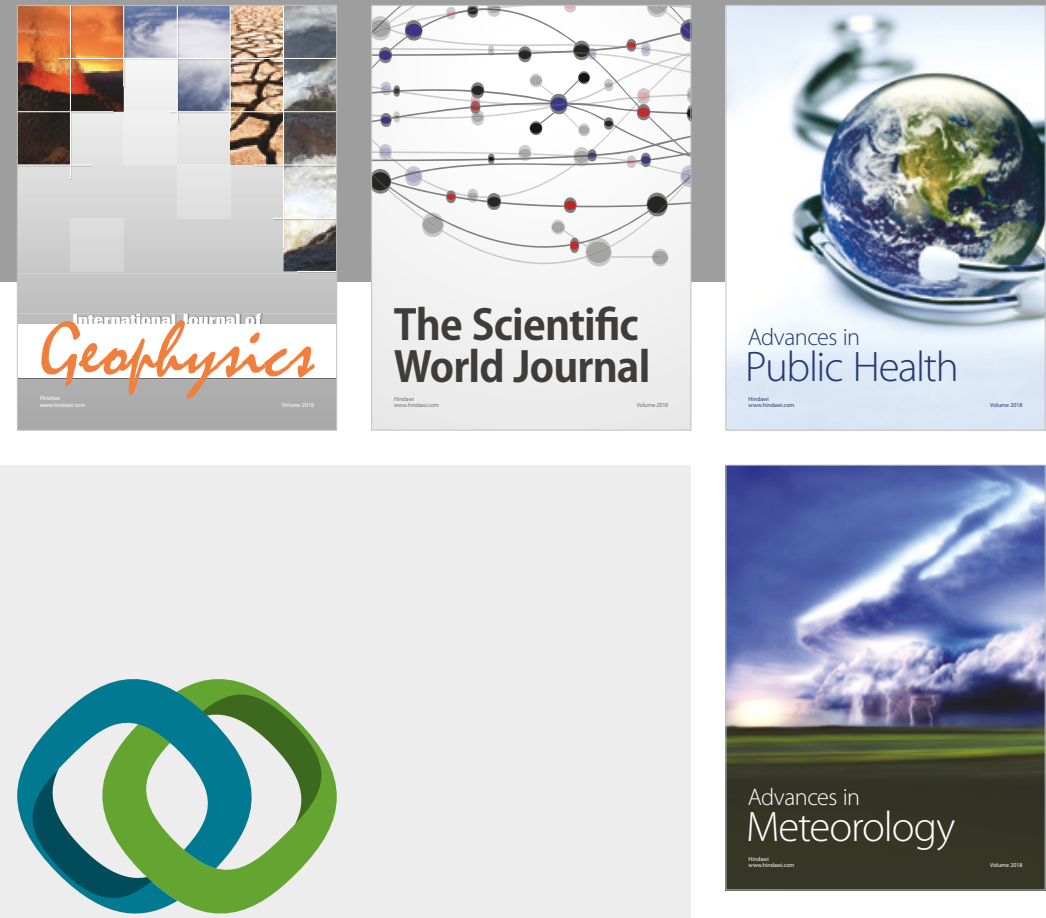

Advan

Public Health

\section{Hindawi}

Submit your manuscripts at

www.hindawi.com
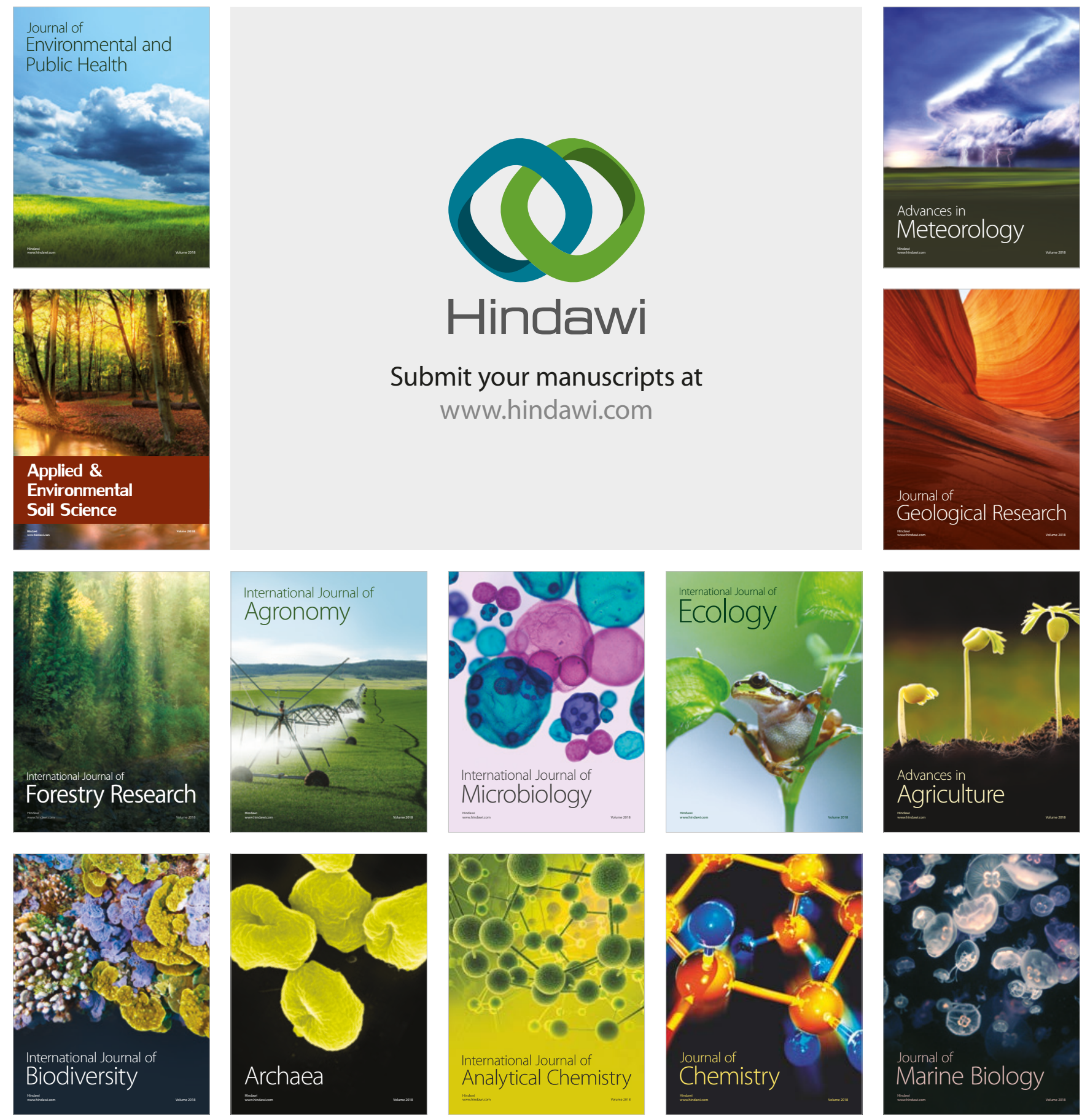